Special issue of the 3rd International Conference on Computational and Experimental Science and Engineering (ICCESEN 2016)

\title{
Bioactivity Properties and Characterization of Commercial Synthetic Hydroxyapatite - 5 wt.\% Niobium (V) Oxide - 5 wt.\% Magnesium Oxide Composite
}

\author{
N. DEMIRKOL* \\ Ceramic, Glass and Tile Department, Vocational School of Degirmendere Ali Ozbay, \\ Kocaeli University, Kocaeli, Turkey
}

\begin{abstract}
Hydroxyapatite is widely used for bone grafts due to its chemical and structural similarities to the mineral phase of hard tissues and due to its bioactivity and biocompatibility. However, hydroxyapatite has poor mechanical properties due to its brittleness. To improve mechanical properties of hydroxyapatite-ceramics, ceramic oxides, whiskers or fibers have been suggested. In this study, commercial synthetic hydroxyapatite composite reinforced with 5 wt. $\% \mathrm{Nb}_{2} \mathrm{O}_{5}$ and 5 wt. $\% \mathrm{MgO}$ was characterized. Microstructural properties of all samples sintered at different temperatures were characterized using scanning electron microscopy technique. Phase analysis was carried out using X-ray diffraction technique. Mechanical properties were measured by compression and hardness tests. The bioactivity property was determined by in vitro bioactivity test. The best obtained values of density, compression strength and Vickers Microhardness were $3.01 \mathrm{~g} / \mathrm{cm}^{3}, 96 \mathrm{MPa}$ and $393 \mathrm{HV}$, for composite sintered at $130{ }^{\circ} \mathrm{C}$ for 4 hours. Bioactivity results for composite, sintered at $1300^{\circ} \mathrm{C}$, show that apatite formation has started after two weeks in a simulated body fluid. At the end of the fourth week, the dense apatite layer and clusters were observed on the surface of the composite.
\end{abstract}

DOI: 10.12693/APhysPolA.132.786

PACS/topics: 87.85.J-

\section{Introduction}

Hydroxyapatite $\left(\mathrm{HA}, \mathrm{Ca}_{10}(\mathrm{PO} 4)_{6}(\mathrm{OH})_{2}\right)$ is the most popular bioceramic material used in orthopedical and dental applications, due to its excellent bioactivity and biocompatibility [1-3]. HA can be obtained by both natural and synthetic methods. The synthetic HA is the most commonly used type of HA, however its fabrication is complex and expensive [2]. On the contrary, natural hydroxyapatite is inexpensive and recyclable [4]. The mechanical properties of HA should match those of the natural bone as closely as possible, to allow for proper bone remodeling at the implant site. HA is typically sintered to enhance the mechanical properties of HA bodies, but the mechanical properties of sintered HA implants are still inferior to those of natural bone $[5,6]$. For this reason, there is a need for improving the mechanical properties of the HA-based bioceramics. Up to now the design of composite materials is one of the primary approaches to control the material properties [7].

In the literature there are very few studies about addition of niobium (V) oxide to HA ceramics. Tamai et al. and Fathi et al. have reported that niobium oxides were promoting the calcification process of human osteoblasts $[8,9]$. Demirkol et al. have investigated the mechanical and microstructural properties of sheep hydroxyapatite - niobium oxide composites [10].

Magnesium was reported to stabilize $\beta$ phase of TCP and to reduce risks of cardiovascular diseases. It is a

\footnotetext{
*e-mail: nermin.demirkol@kocaeli.edu.tr
}

very important element in human body and controls biological functions. It is biocompatible, osteoconductive, osseointegrable and lightweight material with mechanical properties quite similar to those of bone tissue [11-13].

In this study, characterization and bioactivity properties of HA composite with addition of 5 wt.\% of niobium (V) oxide and 5 wt.\% of magnesia, sintered at different temperatures, were investigated.

\section{Materials and methods}

Commercial synthetic hydroxyapatite (CSHA-Acros Org., BE) was used as the major material. Niobium (V) oxide (Alfa Aeser Comp.) and magnesia $(\mathrm{MgO})$ were selected as additives. The CSHA -5 wt. $\% \mathrm{Nb}_{2} \mathrm{O}_{5}-$ 5 wt. $\% \mathrm{MgO}$ powders were mixed together for $4 \mathrm{~h}$ using a ball mill. This mixture (CSHA-5N5M) was pressed at $350 \mathrm{MPa}$ and the pressed samples were sintered at $1000,1100,1200,1300^{\circ} \mathrm{C}$ for $4 \mathrm{~h}\left(+5^{\circ} \mathrm{C} \mathrm{min}^{-1}\right)$. X-ray diffraction (XRD) analysis was carried out using a Brucker D8-Advanced X-ray diffractometer with $\mathrm{Cu} \mathrm{K}_{\alpha}$ radiation. Scanning electron microscopy (SEM) (Jeol JSM5910 LV - Low Vacuum Scanning) and energy dispersive spectroscopy (EDX) (Oxford Inca Energy 200) were used to characterize the microstructure of the composites. Density, Vickers microhardness, and compression strength tests were performed. The hardness measurements of the samples were done using Vickers microhardness testing system (HMV Shimadzu, JP), $200 \mathrm{~g}$ load for $15 \mathrm{~s}$. The compression tests were performed using Universal Testing machine (Shimadzu, JP) at a crosshead speed of $3 \mathrm{~mm} / \mathrm{min}$. In vitro bioactivity test of composite was done with Kokubo SBF solution during soaking time of $1-4$ weeks at $\mathrm{pH}$ of 7.4. 


\section{Results and discussion}

Table I summarizes density and mechanical properties of CSHA-5N5M composite sintered at different temperatures. The best properties were obtained in the composite sample sintered at $1300^{\circ} \mathrm{C}$.

TABLE I

Density, compression strength and Vickers microhardness of CSHA-5N5M composite sintered at different temperatures.

\begin{tabular}{c|c|c|c}
\hline \hline $\begin{array}{c}\text { Temperature } \\
{\left[{ }^{\circ} \mathrm{C}\right]}\end{array}$ & $\begin{array}{c}\text { Density } \\
{\left[\mathrm{g} / \mathrm{cm}^{3}\right]}\end{array}$ & $\begin{array}{c}\text { Compression } \\
\text { strength } \\
{[\mathrm{MPa}]}\end{array}$ & $\begin{array}{c}\text { Vickers } \\
\text { microhardness } \\
{[\mathrm{HV}]}\end{array}$ \\
\hline 1000 & $2.47 \pm 0.07$ & $47 \pm 0.09$ & $97 \pm 1.3$ \\
1100 & $2.69 \pm 0.03$ & $61 \pm 0.03$ & $140 \pm 0.9$ \\
1200 & $2.83 \pm 0.05$ & $78 \pm 0.08$ & $225 \pm 1.1$ \\
1300 & $3.01 \pm 0.07$ & $96 \pm 0.05$ & $393 \pm 0.9$
\end{tabular}

Density and mechanical properties of composite increased with increasing sintering temperature. In former studies, Demirkol et al. studied density and mechanical properties of CSHA [11]. Density, compression strength and Vickers microhardness of CSHA [14] increase with the simultaneous addition of 5 wt. $\% \mathrm{Nb}_{2} \mathrm{O}_{5}$ and 5 wt. $\%$ $\mathrm{MgO}$ to the CSHA by $20 \%, 50 \%$ and $140 \%$, respectively.

Simultaneous addition of niobium (V) oxide and magnesia is more useful than adding them separately, according to physical and mechanical properties [14].

Table II summarizes product phases obtained in XRD diagrams for CSHA-5N5M composite sintered at 1000$1300{ }^{\circ} \mathrm{C}$. Composites sintered at both $1000^{\circ} \mathrm{C}$ and $1300^{\circ} \mathrm{C}$ include hydroxyapatite (HA), whitlockite (betatricalcium phosphate) (W) and calcium magnesium phosphate $\left(\mathrm{CaMgPO}_{4}\right)$. CSHA-5N5M composite sintered at $1300^{\circ} \mathrm{C}$ has shown niobium magnesium phosphate $\left(\mathrm{NbMgPO}_{4}\right)$ phase in addition to these phases. This phase is very effective for improving the mechanical properties of the composite.

\section{TABLE II}

Phases obtained from XRD analysis of CSHA with addition of $5 \mathrm{wt} . \% \mathrm{Nb}_{2} \mathrm{O}_{5}$ and 5 wt. $\% \mathrm{MgO}$ composite sintered at 1000 and $1300{ }^{\circ} \mathrm{C}$.

\begin{tabular}{c|c|c}
\hline \hline & $1000^{\circ} \mathrm{C}$ & $1300^{\circ} \mathrm{C}$ \\
\hline CSHA-5N5M & $\mathrm{Ca}_{10}\left(\mathrm{PO}_{4}\right)_{6}(\mathrm{OH})_{2}(\mathrm{HA})$ & $\mathrm{Ca}_{10}\left(\mathrm{PO}_{4}\right)_{6}(\mathrm{OH})_{2}$ \\
& $\mathrm{Nb}_{2} \mathrm{O}_{5}$ & $\mathrm{Ca}_{3}\left(\mathrm{PO}_{4}\right)_{2}$ \\
& $\mathrm{Ca}_{3}\left(\mathrm{PO}_{4}\right)_{2}(\mathrm{~W})$ & $\mathrm{CaMgPO}_{4}$ \\
& $\mathrm{MgO}$ & $\mathrm{NbMgPO}_{4}$ \\
& $\mathrm{CaMgPO}_{4}$ &
\end{tabular}

Figure 1 presents the micrographs of composites sintered at 1000 and $1300^{\circ} \mathrm{C}$. When Fig. 1a is compared with Fig. 1b, it is seen that grain growth has occurred and porosity of composite has decreased with the increase of sintering temperature.
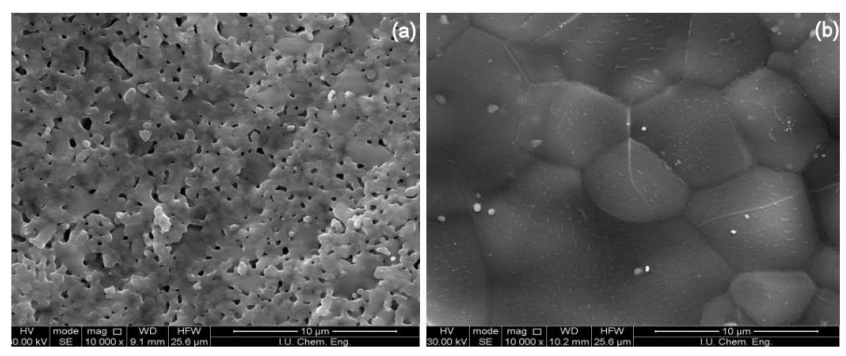

Fig. 1. Microstructures of composites sintered at different temperatures $(\times 10000)$, (a) CSHA-5N5M at $1000^{\circ} \mathrm{C}$, (b) CSHA-5N5M at $1300{ }^{\circ} \mathrm{C}$.

In vitro bioactivity test results of CSHA - 5 wt. $\%$ $\mathrm{Nb}_{2} \mathrm{O}_{5}-5$ wt.\% $\mathrm{MgO}$ composite show that simultaneous addition of $\mathrm{Nb}_{2} \mathrm{O}_{5}$ and $\mathrm{MgO}$ to $\mathrm{HA}$, as reinforcement materials, has a positive effect on formation of apatite. This composite shows a good apatite formation in simulated body fluid (SBF), which indicated bioactivity. Figure 2 shows the TF-FTIR spectrum of apatite coating on the CSHA-5N5M composite sintered at $1300^{\circ} \mathrm{C}$, after the bioactivity test. $\mathrm{O}-\mathrm{H}$ strain mod band and vibration mod peak were positioned at $3354 \mathrm{~cm}^{-1}$ and $1657 \mathrm{~cm}^{-1}$, respectively. Bands at 1041, 598 and $557 \mathrm{~cm}^{-1}$ correspond to $\mathrm{PO}_{4}^{3-} / \mathrm{HPO}_{4}^{2-}$ groups. Bands of carbonate groups are positioned at 1415, 1452 and $872 \mathrm{~cm}^{-1}$. This figure shows that the solid formed in the SBF is the hydroxycarbonapatite.

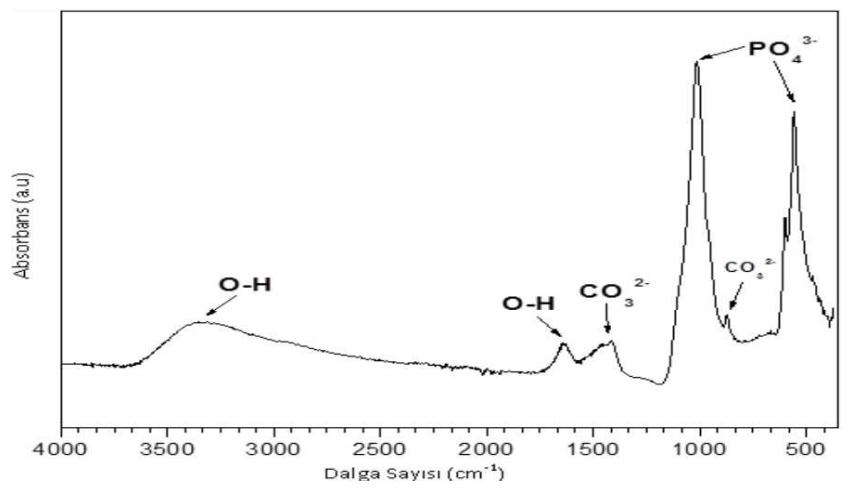

Fig. 2. TF-FTIR spectrum of apatite coating formed during the bioactivity test of CSHA-5N5M composite, sintered at $1300^{\circ} \mathrm{C}$.

\section{Conclusions}

The findings of this study are summarized as follows:

Mean density values and mechanical properties of CSHA-5N5M composite increase with increasing sintering temperature. Using $\mathrm{Nb}(\mathrm{V})$ oxide and magnesium oxide together, as the reinforcement materials for improvement of mechanical properties, is better than using them separately.

The highest density, compression strength and Vickers microhardness values were obtained for composite sintered at $1300^{\circ} \mathrm{C}$.

This material is a good candidate for orthopedical applications. 


\section{References}

[1] N. Demirkol, F.N. Oktar, E.S. Kayali, Acta Phys. Pol. A 121, 274 (2012)

[2] N. Demirkol, A.Y. Oral, F.N. Oktar, E.S. Kayali, Key Engin. Mater. 587, 33 (2014).

[3] S. Ozturk, M. Yetmez, Adv. Mater. Sci. Engin. 2016, 6987218 (2016).

[4] F. Heidari, M. Razavi, M. Ghaedi, M. Forooghi, M. Tahriri, L. Tayebi, J. Alloy. Compd. 693, 1150 (2017)

[5] R. Chakraborty, D. RoyChowdhury, Chem. Eng. J. 215-216, 491 (2013).

[6] V.S. Gshalaev, A.C. Demirchan, Hydroxyapatite Synthesis, Properties and Applications, Nova Science Publisher, 2012.

[7] K. Lin, M. Zhang, W. Zhai, H. Qu, J. Chang, J. Am. Ceram. Soc. 94, 206 (2011).
[8] M. Tamai, K. Isama, R. Nakaoka, T. Tsuchiyo, J. Artif. Organs 10, 22 (2007).

[9] M.H. Fathi, M. Salehi, V. Martazavi, S.B. Mousavi, A. Porsapour, Surf. Eng. 22, 353 (2006).

[10] N. Demirkol, F.N. Oktar, E.S. Kayali, Acta Phys. Pol. A 121, 274 (2012).

[11] H.-S. Ryu, K.S. Hong, J.-K. Lee, D.J. Kim, J.-H. Lee, B.-S. Chang, D.-H. Lee, C.-K. Lee, S.-S. Chung, Biomater. 25, 393 (2004)

[12] N. Demirkol, O. Meydanoglu, H. Gokce, F.N. Oktar, E.S. Kayali, Key Engin. Mater. 493-494, 588 (2012).

[13] R. del Compo, B. Savoini, A. Munoz, M.A. Monge, R. Pareja, J. Mechan. Behav. Biomed. Mater. 69, 135 (2017).

[14] N. Demirkol, Koyun Hidroksiapatit Esasl Kompozitlerin Üretimi ve Karakterizasyonu, Yalın Yayıncılık, 2016, s. 80. 